\title{
Pengaruh kepemimpinan dan komunikasi terhadap kepuasan kerja karyawan kuta paradiso hotel
}

\author{
I Kadek Arsana ${ }^{1)}$, Drs. Ida Bagus Ketut Astina ${ }^{2)}$ Fanny Maharani Suarka $^{3)}$ \\ Program Studi Diploma IV Pariwisata, Fakultas Pariwisata, Universitas Udayana \\ J1. DR. R. Goris No. 07, Denpasar, Kode pos: 80232, Tlpn/Fax: 0361223798 \\ E-mail: arsanakadek1@gmail.com ${ }^{1)}$
}

\begin{abstract}
Abstrak
Kepuasan kerja karyawan hal penting menjadi perhatian bagi perusahaan, beberapa masalah seperti kepemimpinan dan komunikasi salah satu penyebab kary awan tidak berkontribusi baikpadaperusahaan.Kuta Paradiso Hotel Bali terdapat keluhan terkait kepemimpinan dimana kekuas aan dan we wenang mutlakberada pada pimpinan, serta kurangny a komunikasi terkait aturan jamkerja yang tidak dipatuhi oleh karyawan dan tingginya absensi karyawan. Tujuan penelitian ini adalah untuk mengetahuibag aimanapenganuhkepempinan dan komunikasiterhadap kepuas an kerja karyawan di Kuta Paradiso HotelBali dan untuk mengetahuivariabel yang lebih berpengaruh antara kepemimpinan dan komunikasiterhadap kepuas an kerja karyawan di Kuta Parad is o Hotel Bali. Teknik pengumpulan data yaitu observasi, kuesioner, stud ikepustakaan,dandokumentasi. Teknik peng ambilan sampel y ang digunakan dalampenelitian ini adalah Teknik Nonprobability Sampling dengan jenis sampling jenuh istilah lainnya sensus, dimana semua anggota populasidijadikan sampel. Populasi penelitian ini adalah karyawan Human Resources, Sales \& Marketing dan, Accounting department diKuta Paradiso Hotel Bali. Penelitian ini menggunakan teknik analis is kualitatif dan teknik analisis kuantitatif diantaranya analis is skala likert, uji validitas, uji reliabilitas uji as umsi klasik, regresi linierberganda, uji F, uji $\mathrm{t}$ dan analis is koefisien determinasi. Hasil analis is hipotesis pertama tentang peng aruh kepemimpinan dan komunikasi terhadap kepuasan kerja karyawan di Kuta Paradiso Hotel Bali memiliki pengaruh positif dan signifikan pada kepuas an kerja karyawan dengan nilait hitung 4,915 dengan t tabel sebes ar1,6artinyasemakin baik kepemimpinan maka semakin tinggi kepuas an kerja karyawan di Kuta Paradiso Hotel, dan Berdasarkan hasil analisis variabel kepemimpinan dan komunikasilebih berpengaruh terhadap kepuas an kerja karyawan yaitu Komunikasiberpengaruh positif dan signifikan terhadap kepuasan kerja deng an nilai thitung sebesar 3,548 dengan $t$ tabel sebesar 1,6 ini berarti semakin baik komunikasi maka semakin tinggi kepuasan kerja karyawan di Kuta Paradiso Hotel.
\end{abstract}

Kata kunci: Kepemimpinan, Komunikasi dan Kepuasan Kerja

\begin{abstract}
Employee job satisfaction is an important concern for the company, several issues such as leadershipand communication are one of the reasons employees do not contribute well to the company.KutaParadisoHotel Bali has complaints about leadership where absolute power and authority rest withtheleadership, aswellas lack of communication related to working hours rules that are not a dhered tobyemployeesandhighemployee absences. The purpose of this study was to determine how leadership and communicationinfluenceemployee job satisfaction at Kuta Paradiso Hotel Bali and to find out more influentialvariablesbetweenleadershipand communication on employee job satisfaction at Kuta Paradiso Hotel Bali. Data collection techniquesare observation, questionnaire, literature study, and documentation. The sampling techniqueusedinthisstudyis the Nonprobability Sampling Technique with other types of saturated census sampling, whereallmembersof the population are sampled. The population of this study are employees of Human Resources, Sales \& Marketing and, Accounting department at Kuta Paradiso Hotel Bali. This study uses qualitative analysis techniques and quantitative analysis techniques including Likert scale analysis, validitytest, reliabilitytest classic assumption test, multiple linear regression, F test, t test and analysis ofthecoefficientofdetermination. The results of the first hypothesis analysis about the influence ofleadership and communicationonemployee job satisfaction at Kuta Paradiso Hotel Bali has a positive and significant effect on employeejobsatisfaction with a tcount of 4.915 with a t table of 1.6, meaning the better the leadership the higherthejobsatisfaction of employees at Kuta Paradiso Hotel, and Based on the results of the analysis ofleadershipandcommunication variables more influential on employee job satisfaction, namely Communicationhasa positiveandsignificant effect on job satisfaction with a t value of 3.548 with a t table of 1.6 this means the better thecommunication the higher job satisfaction employee at Kuta Paradiso Hotel.
\end{abstract}

Keywords: Leadership, Communication and Job Satisfaction 


\section{PENDAHULUAN}

Bali merupakan salah satu daerah tujuan wisata utama yang berada di Indonesia yang telah mendapat perhatian dari pemerintah dalam pariwisatanya. Pariwisata adalah aktivitas perjalanan yang dilakukan oleh sementara waktu dari tempat tinggal semula ke daerah tujuan dengan alasan bukan untuk menetap atau mencari nafkah melainkan hanya untuk memenuhi rasa ingin tahu, menghabiskan waktu senggang atau libur serta tujuan-tujuan lainnya.

Tabel 1. Tabel Tingkat Kunjungan W isatawan Nusantara dan Mancanegarake Bali Tahun 2013-2017

\begin{tabular}{|c|c|c|c|c|}
\hline \multirow{2}{*}{ Tahun } & \multicolumn{2}{|c|}{ Jumlah Wisatawan (orang) } & \multirow{2}{*}{$\begin{array}{c}\text { Total Wisatawan } \\
\text { (orang) }\end{array}$} & \multirow{2}{*}{ Pertumbuhan (\%) } \\
\hline & Mancanegara & Nusantara & & \\
\hline 2013 & 3.278 .598 & 6.976 .536 & 10.255 .134 & - \\
\hline 2014 & 3.766 .638 & 6.392 .460 & 10.159 .098 & $-0,94$ \\
\hline 2015 & 4.001 .835 & 7.147 .100 & 11.148 .935 & 8,88 \\
\hline 2016 & 4.927 .937 & 8.643 .680 & 13.571 .617 & 17,85 \\
\hline 2017 & 5.697 .739 & 8.645 .788 & 14.343 .527 & 5,38 \\
\hline \multicolumn{4}{|c|}{ Rata-rata pertumbuhan } & 7,79 \\
\hline
\end{tabular}

Sumber: Pus at Statis tik Provinsi Bali, 2018.

Berdasarkan data Tabel 1, diketahui bahwa jumlah kunjungan wisatawan mancanegara dan nusantara mengalami peningkatan setiap tahunnya dengan rata-rata pertumbuhan sebesar 7,79\%. Meningkatnya jumlah kunjungan wisataw an tersebut dikarenakan adanya perhatian dan promosi yang cukup baik untuk sektor pariw is ata dari Pemerintah dan berbagai pihak mas yarakat. Dilihat dari kondisi peningkatan tersebut tentunya menyebabkan tingkat persaingan dalam industri pariwisata semakin ketat.

Tabel 2. Data Karyawan Berdasarkan Level Manajemen Kuta Paradiso Hotel Bali

\begin{tabular}{|l|c|c|c|}
\hline \multirow{2}{*}{ Departemen } & \multirow{2}{*}{$\begin{array}{c}\text { Jumlah } \\
\text { Karyawan }\end{array}$} & Laki-laki & Merempuan \\
\cline { 3 - 4 } & 31 & 23 & 8 \\
\hline Accounting & 10 & 1 & 9 \\
\hline Sales Marketing & 26 & 14 & 12 \\
\hline Front Office & 46 & 41 & 27 \\
\hline Housekeeping \& Loundry & 122 & 95 & 1 \\
\hline F\&B & 31 & 30 & 1 \\
\hline Engineering & 3 & 2 & 1 \\
\hline HRD & 20 & 19 & 64 \\
\hline Security & 289 & 225 & \\
\hline \multicolumn{1}{|c|}{ Total } & & & \\
\hline
\end{tabular}

Sumber : Data HRD Kuta Paradiso Hotel Bali, 2018

Berdasarkan tabel 2 maka dapat terlihat bahwa jumlah karyawan yang dimiliki oleh Kuta Paradiso Hotel Bali adalah sebanyak 289 orang dengan 225 orang pekerja laki-laki dan 64 orang pekerja perempuan.

Tabel 3. .Keluhan Karyawan Kuta Paradiso Hotel Bali

\begin{tabular}{|l|c|l|c|}
\hline No & \multicolumn{1}{|c|}{ Department } & \multicolumn{1}{|c|}{ Keluhan } & Jumlah \\
\hline \multirow{2}{*}{1.} & Human Resources & $\begin{array}{l}\text { Kurangnya komunikasiyang baik antarsesama rekan } \\
\text { kerja. }\end{array}$ & $\begin{array}{l}\text { Beban kerja yang diberikan tidak sesuai dengan yang } \\
\text { didapatkan. }\end{array}$ \\
\hline \multirow{2}{*}{2.} & \multirow{2}{*}{ Sales \& Marketing } & $\begin{array}{l}\text { Adanya hubungan yang kurang baik antar sesame rekan } \\
\text { kerja. }\end{array}$ & 1 \\
\cline { 3 - 4 } & $\begin{array}{l}\text { Ketidaknyamananyang terjadiantara atasan dengan } \\
\text { bawahan. }\end{array}$ & 2 \\
\hline
\end{tabular}




\begin{tabular}{|l|l|l|c|}
\hline & & Pengambilan keputusan atasan yang kurang adil. & 1 \\
\hline \multirow{2}{*}{3.} & \multirow{2}{*}{ Accounting } & Ketidaknyamanan yang terjadi antar sesama rekan kerja. & 5 \\
\cline { 3 - 4 } & & Peluang promosi yang dirasakan kurang adil & 4 \\
\hline \multicolumn{2}{|c|}{ Total } & 15 \\
\hline
\end{tabular}

Sumber: Karyawan Kuta Paradiso Hotel Bali

Berdasarkan tabel 3, dari ketiga department jumlah keluhan karyawan diatas totalnya 15 orang dan saat ini masih adanya permasalahan yang terjadi, dari hal tersebut penelitian ini akan menilai kepemimpinan dari ketiga department di atas yaitu HRM, DOS, dan FC yang menyebabkan kurang kepuasan kerja seorang karyawan dalam menjalankan tugasnya selama berada di perusahaan.

Tabel4. Tingkat Absensi Karyawan Di Kuta Paradiso Hotel Periode 2018

\begin{tabular}{|l|c|c|c|c|c|c|}
\hline Department & Januari & Februari & Maret & April & Mei & Juni \\
\hline Accounting & 2 & 8 & 10 & 16 & 12 & 1 \\
\hline Sales \& Marketing & 5 & 0 & 1 & 1 & 1 & 2 \\
\hline Front Office & 16 & 19 & 22 & 18 & 17 & 3 \\
\hline House Keeping & 6 & 43 & 43 & 42 & 41 & 7 \\
\hline F\&B & 26 & 39 & 46 & 41 & 37 & 19 \\
\hline Engineering & 2 & 20 & 13 & 17 & 13 & 15 \\
\hline HRD & 2 & 0 & 1 & 2 & 1 & 0 \\
\hline Security & 2 & 1 & 1 & 3 & 2 & 2 \\
\hline Jumlah & 61 & 130 & 137 & 140 & 124 & 49 \\
\hline
\end{tabular}

Sumber : HRD Kuta Paradiso Hotel Bali, 2018.

Berdasarkan tabel 4, maka tingkat absensi ketidakhadiran paling tinggi yaitu pada bulan april sebesar 140 orang, hal ini disebabkan pada saat bulan april terjadi pemindahan lokasi absensi karyawan, yang pada awalnya berlokasi di dekat area parkir karyawan menjadi berpindah kelokasi dekat hotel yaitu di pintu masuk tunnel (jalan menuju ke hotel).Dari adanya pemindahan lokasi absensi tersebut membuat para karyaw an menjadi lebih harus tepat waktu untuk melakukan absensi pada aw al bekerja, yang sebelumnya para karyawan terbiasa meleluasakan waktu kehadiran akibat jarak absensi yang berada di dekat area parkir dan tingkat absensi ketidakhadiran paling rendah yaitu berada pada bulan juni sebesar 49 orang. Dilihat dari banyaknya tingkat absensi karyawan yang terlambat maka perlu adanya motivasi yang baik terhadap karyawan.

\section{METODE PENELITIAN}

Definisi operasional variabel digunakan untuk memperjelas dan mempertegas yang diteliti. Maka berikut akan dijelaskan variabel yang terdapat dalam pemersalahan yang dibahas sebagai berikut:

Tabel 5. Variabel dan Indikator

\begin{tabular}{|c|l|ll|}
\hline Variabel & \multicolumn{1}{|c|}{ Konsep } & & \multicolumn{1}{c|}{ Indikator } \\
\hline Kepemimpinan & Anogara (2005:182), & 1. & Kejujuran \\
& Gorda (2004:166), & 2. & Kesetiaan Dan Tidak Ingkar Janji \\
& Siswanto (2005). & 3. & Dedikasi Yang Tinggi \\
& & 4. & Inisiatif, Kreativitas Dan Inovatif \\
& & 5. & Wawasan Yang Luas \\
& & 6. & Terpadu Dan Pengalaman \\
& & 7. & Bertanggung Jawab. \\
\hline Komunikasi & Robbins (2001:314- & 1. & Komunikasi vertikal \\
$\left(\mathrm{X}^{2}\right)$ & 315), & 2. & Komunikasi horizontal \\
& Handoko (2004:30), & 3. & Komunikasi diagonal \\
& Effendi (2005:17), & 4. & Teknik komunikasi \\
\hline
\end{tabular}




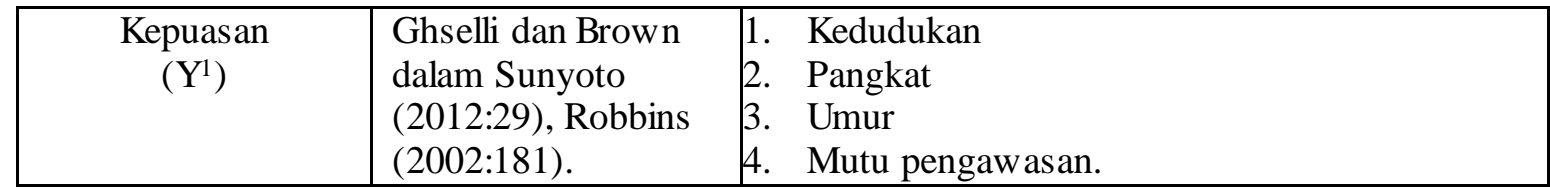

Sumber :Gorda (2004), Sunyoto (2012)

Jenis data yang di gunakan yaitu data kualitatif dan kuantitatif . Data kualitatif Menurut Sugiyono (2003:14), data kualitatif merupakan data yang berbentuk kalimat, katau ataupun gambar. Dapat dijelaskan bahw a data kualitatif merupakan data berupa kata-kata, uraian atau deskripsi. Pada penulisan penelitian ini yang disebut data kualitatif adalah : gambaran umum hotel, sejarah hotel dan struktur organisasi. Dan data kuantitatif Menurut Sugiyono (2003:19), data kuantitatif adalah data yang berbentuk angka atau data kualitatif yang diangkakan (skoring). Pada penulisan penelitian ini yang dimaksud data kuantitatif adalah jumlah karyaw an yang mengikuti pelatihan, tingkat absensi karyawan

Sumber data dalam penelitian ini terbagi menjadi dua bagian, yaitu : Data primer Data Primer adalah data yang diperoleh secara langsung oleh pengumpul data (Sugiyono, 2008:137). Sumber data yang diperoleh dalam penelitian ini adalah penyebaran kuisioner pada responden. Dan data sekunder, Data sekunder merupakan data yang diperoleh secara tidak langsung, bisa melalui pihak lain atau lew at dokumen (Sugiyono, 2008:137). Data sekunder merupakan data yang tidak didapatkan sendiri melainkan dari penelitian orang lain, tetapi ikut mendukung permasalahan dalam penelitian, seperti sejarah hotel atau perusahaan, struktur organisasi. Adapun teknik pengumpulan data yang digunakan untuk mengumpulkan data penunjang penelitian ini adalah observasi, waw ancara, kuesioner, studi kepustakaan, dan dokumentasi.

Observasi merupakan metode pengumpulan data dengan mengadakan pengamatan langsung ke lokasi terkait untuk memperoleh informasi yang jelas terkait lokasi/desa ataupu suatu akomodasi yang akan diteliti (Sugiyono, 2013:145). Wawancara merupakan teknik pengumpulan data yang dilakukan dengan mengadakan tanya jawab secra langsung dengan sumber-sumber yang terkait dengan penelitian (Sugiyono, 2013:231). Kuesioner merupakan pengumpulan data dengan cara memberikan daftar pertanyaan kepada responden, teknik ini dipakai untuk mengetahui tanggapan mengenai pengaruh kepemimpinan dan komunikasi terhadap kepuasan kerja karyawan di Kuta Paradiso Hotel (Sugiyono, 2013:81). Wawancara merupakan teknik pengumpulan data yang dilakukan dengan mengadakan tanya jawab secra langsung dengan sumber-sumber yang terkait dengan penelitian (Sugiyono, 2013:231). Waw ancara dalam penelitian ini ditunjukan kepada Human Resources Manager di Kuta Paradiso Hotel.

Teknik penentuan informan yang digunakan dalam penelitian ini adalah teknik purposive sampling, yaitu teknik penentuan sampel dengan pertimbangan tertentu untuk mendapatkan informasi dari informan pangkal dan informan kunci (Sugiyono, 2016:85).

Teknik pengambilan sampel yang di gunakan dalam penelitian ini adalah Teknik Nonprobability Sampling dengan jenis sampling jenuh istilah lainnya sensus, dimana semua anggota populasi dijadikan sampel. Adapun yang akan menjadi populasi dalam penelitian ini adalah Karyaw an Human Resources, Sales \& Marketing dan, Accounting department di Kuta ParadisoHotel Bali, karyaw an kontrak yang berjumlah 44 orang diantaranya Human Resources 3 karyawan, Sales \& Marketing 10 karyaw an dan, Accounting department berjumlah 31 karyawan.

Analisis data dalam penelitian ini memiliki beberapa tahap, dimana tahapan tersebut digunakan untuk membantu menyelesaikan rumusan masalah yang telah dipaparkan. Pengolahan data dan analisisnya menggunakan beberapa tahap yaitu analisis deskriptif kualitatif, analisis deskriptif kuantitatif. Kuesioner yang digunakan dalam penelitian ini adalah kuesioner tipe pilihan yang artinya karyaw an yang sebagai responden diberikan alternatif jawaban yang telah disediakan dengan menggunakan skala likert. Jawaban setiap item instrument mempunyai gradasi dari sangat positif sampai negatif dengan nilai perhitungan sebagai berikut

Nilai Tertinggi-Nilai Terendah Jumlah Kategori 


$$
\frac{5-1}{5}=0,8
$$

Berdasarkan rumus interval yang dijelaskan sebelumnya maka dapat disusun kategori sikap wisatwan seperti Tabel 6. berikut ini:

Tabel 6. Kategori Penilaian Skala Likert

\begin{tabular}{|c|l|c|c|}
\hline No & \multicolumn{1}{|c|}{ Pilihan Jawaban } & Skor & Rentang Nilai (Interval) \\
\hline 1. & Sangat Setuju & 5 & $4,21-5,00$ \\
\hline 2. & Setuju & 4 & $3,41-4,20$ \\
\hline 3. & Kurang Setuju & 3 & $2,61-3,40$ \\
\hline 4. & Tidak Setuju & 2 & $1.81-2,60$ \\
\hline 5. & Sangat Tidak Setuju & 1 & $1,00-1,80$ \\
\hline
\end{tabular}

Sumber: Hasil Modifikasi Skala Likert (Kusmayadi \& Endar, 2000:94

Uji Validitas digunakan untuk mengetahui apakah setiap butir pertanyaan atau pertanyan dalam kuisioner itu valid. Dalam menetapkan validitas suatu instrumen dengan melakukan analisis statistik yang dibantu dengan program komputer statistical package of social science (SPSS) ver 16 for windows.

Uji Reliabilitas digunakan untuk mengetahui apakah instrumen tersebut dapat di percaya, handal dan akurat. Dalam pengujian reliabilitas digunakan uji konsistensi internal dengan menggunakan rumus alpha cronbach seperti di bawah ini yang diproses didalam program komputer statistical package of social science (SPSS) ver 16 for windows.

Rumus:

$$
\mathrm{a}=\frac{k}{k-1}\left(1 \frac{\sum \mathrm{s} 2 \mathrm{j}}{s 2 x}\right)
$$

Keterangan :

$\mathrm{a}=$ koefisien reliabilitas alpha

$\mathrm{k}=$ jumlah item

$\mathrm{Sj}=$ varians responden

$\mathrm{Sx}=$ jumlah varians skor total

Kreteria suatu instrumen penlitian dikatakan reliabel dengan menggunakan teknik ini bila koefisien reliabilitas sebagai berikut:

Tabel 7. Interpretasi Terhadap Reliabilitas

\begin{tabular}{|l|l|}
\hline \multicolumn{1}{|c|}{ Jika Alpha atau r hitung } & \multicolumn{1}{c|}{ Kategori } \\
\hline $0,8-1,0$ & Reliabilitas baik \\
\hline $0,6-0,799$ & Reliabilitas diterima \\
\hline $0,5-0,599$ & Reliabilitas kurang baik \\
\hline$<0,5$ & Reliabilitas tidak diterima \\
\hline
\end{tabular}

Sumber : Sugiyono, 2013.

Uji Asumsi Klasik untuk menguji apakah persamaan garis regresi yang di peroleh linier dan bisa dipergunakan untuk melakukan peramalan maka harus dilakukan uji asumsi klasik. Regresi linear berganda digunakan untuk meramalkan bagaimana variabel terikat, bila dua atau lebih variabel bebas sebagai faktor prediktor (Sugiyono 2013). Dan untuk mengetahui seberapa besar pengaruh variabel bebas terhadap variabel terikat. Analisis Uji t-test ini bertujuan untuk membuktikan apakah korelasi yang diperoleh antara gaya kepemimpinan dan motivasi kerja dengan semangat kerja karyaw an pada Kuta Paradiso Hotel Bali memang benar atau di dapat secara kebetulan. Menurut Sugiyono (2008) uji F digunakan untuk menguji variabel - variabel bebas secara bersama-sama terhadap variabel terikat. Selain itu dengan uji $\mathrm{F}$ ini dapat diketahui pula apakah model regresi linier yang digunakan sudah tepat atau belum. Analisis Koefisien Determinasi, analisis ini digunakan untuk mengukur seberapa besar pengaruh kepemimpinan dan motivasi kerja terhadap semanngat kerja karyaw an yang dinyatakan dalam persentase. Untuk mencari koefesien determinasi dapat dihitung jalan mengkwadratkan korelasi dikalikan seratus pesan. 


\section{HASIL DAN PEMBAHASAN}

Kuta Paradiso Hotel buka pada tahun 1996, hotel ini aw alnya bernama Sol Elite Paradiso dan pada tahun 1998 manajemen berubah dan nama Sol Elite Paradiso berubah menjadi Kuta Paradiso Hotel, kepemilikan PT.Gria Wijaya Prestige. Hotel ini di bangun dengan fasilitas hotel berbintang 5 yang bertema resor di tengah area Kuta. Memiliki kamar 257 kamar Deluxe, kamar super Deluxe dan suite yang di atur di dalam dua sayap bangunan yang mengarah ke loby Hotel yang luas, yang membuatnya tampak menarik. Letak berdirinya Kuta Paradiso Hotel merupakan lokasi yang sangat strategis di tengah keramaian pusat turis di Kuta, untuk mencapai Seminyak, Denpasar, dan Nusa Dua pun tidak jauh. Berdekatan dengan pantai Kuta, pasar tradisional, pasar oleh-oleh, kuliner khas Bali, dan bersebelahan dengan pusat berlibur yang terkenal di Bali.

Hasil penelitian yang dilaksanakan, dapat dijelaskan gambaran mengenai responden berdasarkan umur, jenis kelamin, pendidikan, serta masa kerja.

1. Responden Berdasarkan Umur

Komposisi responden berdasarkan umur dapat dilihat pada Tabel 7. di bawah ini.

Tabel 7. Karakteristik Menurut Umur Responden

\begin{tabular}{|c|c|c|}
\hline Umur (Tahun) & Jumlah (Orang) & Persentase \\
\hline $21-30$ & 8 & 18,2 \\
\hline $31-40$ & 12 & 27,3 \\
\hline $41-50$ & 20 & 45,5 \\
\hline$>50$ & 4 & 9,1 \\
\hline Total & 44 & 100 \\
\hline
\end{tabular}

Sumber : HRD Kuta Paradiso Hotel, Tahun 2019

Berdasarkan Tabel 7, dapat dilihat bahwa responden umur $41-50$ sebanyak 20 orang $(45,5 \%)$ merupakan jumlah tertinggi dibandingkan dengan kelompok umur yang lain, hal ini mengindikasikan bahwa pihak hotel dikelola oleh tenaga kerja dengan kelompok umur dewasa.

2. Responden Berdasarkan Jenis Kelamin

Komposisi responden berdasarkan jenis kelamin dapat dilihat pada Tabel 8. di bawah ini.

Tabel 8. Karakteristik Responden Berdasarkan Jenis Kelamin

\begin{tabular}{|l|c|c|}
\hline \multicolumn{1}{|c|}{ Jenis Kelamin } & Jumlah (Orang) & Persentase \\
\hline Laki-laki & 24 & 54,5 \\
\hline Perempuan & 20 & 45,5 \\
\hline Total & 44 & 100 \\
\hline
\end{tabular}

Sumber : HRD Kuta Paradiso Hotel, Tahun 2019

Berdasarkan Tabel 8, dapat bahwa jumlah karyawan laki-laki lebih banyak dibandingkan dengan karyawan perempuan, hal ini dikarenakan karyawan laki-laki lebih diperlukan untuk mengisi shift malam dalam operasional hotel.

3. Responden Berdasarkan Pendidikan

Komposisi responden apabila diklasifikasikan berdasarkan pendidikan dapat dilihat pada Tabel 9. di baw ah ini.

Tabel 9. Karakteristik Responden Berdas arkan Pendidikan

\begin{tabular}{|l|c|c|}
\hline Pendidikan & Jumlah (Orang) & Persentase \\
\hline & & \\
\hline SMA/SMK & 14 & 31,8 \\
\hline Diploma & 20 & 45,5 \\
\hline Sarjana & 10 & 22,7 \\
\hline Total & 44 & 100 \\
\hline
\end{tabular}

Sumber : HRD Kuta Paradiso Hotel, Tahun 2019

Berdasarkan Tabel 9, dapat dilihat bahwa, jumlah karyawan yang pendidikan diploma lebih banyak daripada tingkat pendidikan lainnya hal ini mengidikasikan pihak hotel mengoperasikan hotel menggunakan tenaga kerja yang berpendidikan tinggi. 
Berdasarkan jumlah responden yang dijadikan sampel dalam penelitian ini sebanyak 44 responden. Penelitian dilakukan dengan mengajukan kuesioner dimana variabel kepemimpinan terdiri dari 7 pernyataan, komunikasi sebanyak 9 pernyataan, dan kepuasan kerja terdiri dari 10 pernyataan. Untuk mendapatkan penilaian secara kualitatif dipergunakan skor rata-rata jawaban responden dengan kriteria dan kategori penilaian jaw aban kuisioner seperti Tabel 10. sebagai berikut. Tabel 10. Kriteria Penilaian Jawaban Kuisioner Kepemimpinan, Komunikasi, Dan Kepuasan Kerja

\begin{tabular}{|c|c|}
\hline Kriteria & Kategori Penilaian \\
\hline $1,00-1,80$ & Sangat kurang baik \\
$1,81-2,60$ & Kurang baik \\
$2,61-3,40$ & Cukup baik \\
$3,41-4,20$ & Baik \\
$4,21-5,00$ & Sangat baik \\
\hline
\end{tabular}
berikut:

Adapun persepsi variabel kepemimpinan, komunikasi, dan kepuasan kerja adalah sebagai

1. Penilaian Responden Variabel Kepemimpinan $\left(\mathrm{X}_{1}\right)$

Tabel 11. Distribusi Tanggapan Responden Pada Variabel Kepemimpinan

\begin{tabular}{|c|c|c|c|c|c|c|c|}
\hline \multirow[b]{2}{*}{ Indikator } & \multicolumn{5}{|c|}{ Jawaban } & \multirow[b]{2}{*}{ Total } & \multirow[b]{2}{*}{ Mean } \\
\hline & STS & TS & KS & $S$ & SS & & \\
\hline Kejujuran & 0 & 0 & 17 & 21 & 6 & 165 & 3,75 \\
\hline Kesetiaan dan tidak ingkar janji & 0 & 0 & 17 & 21 & 6 & 165 & 3,75 \\
\hline Dedikasi yang tinggi & 0 & 0 & 17 & 21 & 6 & 165 & 3,75 \\
\hline Inis iatif, kreatifitas dan inovatif & 0 & 0 & 17 & 21 & 6 & 165 & 3,75 \\
\hline W awas an y ang luas & 0 & 0 & 16 & 21 & 7 & 167 & 3,8 \\
\hline Terpadu dan pengalamanan & 0 & 0 & 11 & 24 & 9 & 174 & 3,95 \\
\hline Bertanggungjawab & 0 & 0 & 18 & 20 & 6 & 164 & 3,73 \\
\hline Rata-rata variable & & & & & & & 3,78 \\
\hline
\end{tabular}

Sumber: data diolah, 2019

Berdasarkan Tabel 11, terlihat bahwa rata-rata skor dari 7 pernyataan mengenai kepemimpinan yaitu sebesar 3,78 yang berada pada kisaran 3,41-4,20 yang berarti baik. Hal ini berarti responden dalam penelitian ini menilai kepemimpinan adalah baik. Hal tersebut nampak dari indikator kejujuran diketahui sebanyak 21 responden setuju bahw a kepemimpinan yang ada di Hotel Kuta Paradiso memiliki sifat jujur. Pada indikator kesetiaan dan tidak ingkar janji diketahui sebanyak 21 responden yang menyatakan sikap setuju. Pada indikator dedikasi yang tinggi, inisiatif, serta wawasan masing-masing dijawab oleh 21 responden dengan respon setuju.

2. Penilaian Responden Variabel Komunikasi $\left(\mathrm{X}_{2}\right)$

Tabel 12. Distribusi Tanggapan Responden Pada Variabel Komunikasi

\begin{tabular}{|c|c|c|c|c|c|c|c|}
\hline \multirow{2}{*}{ Pernyataan } & \multicolumn{5}{|c|}{ Jawaban } & \multirow[b]{2}{*}{ Total } & \multirow[b]{2}{*}{ Mean } \\
\hline & STS & TS & KS & $S$ & SS & & \\
\hline $\begin{array}{l}\text { Atasan mengkomunikasikan informasi } \\
\text { megenai tugas, kebijakan-kebijakan } \\
\text { terkait organisasi }\end{array}$ & 0 & 0 & 19 & 22 & 3 & 160 & 3,64 \\
\hline $\begin{array}{l}\text { Atasan mengkomunikasikan hasil kerja } \\
\text { saya }\end{array}$ & 0 & 0 & 18 & 24 & 2 & 160 & 3,64 \\
\hline $\begin{array}{l}\text { Karyawan dengan mudah dapat } \\
\text { melakukan hubungan komunikasi } \\
\text { dengan atasan }\end{array}$ & 0 & 0 & 19 & 21 & 4 & 161 & 3,66 \\
\hline $\begin{array}{l}\text { Setiap kendala pekerjaan yang terjadi } \\
\text { di komunikasikan kepada atasan }\end{array}$ & 0 & 0 & 18 & 23 & 3 & 161 & 3,66 \\
\hline
\end{tabular}




\begin{tabular}{|l|c|c|c|c|c|c|c|}
$\begin{array}{l}\text { Karyawan percayaterhadap rekan kerja } \\
\text { di dalam melakukan pekerjaan }\end{array}$ & 0 & 0 & 17 & 25 & 2 & 161 & 3,66 \\
\hline $\begin{array}{l}\text { Dengan rekan kerja, kordinasidan } \\
\text { kerjasama terhadappenyelesaian } \\
\text { pekerjaan dapat dengan mudah } \\
\text { terbentuk }\end{array}$ & 0 & 0 & 14 & 25 & 5 & 167 & 3,8 \\
\hline $\begin{array}{l}\text { Perbedaan jabatan tidak menjadi } \\
\text { penghalang bagi karyawan dalam } \\
\text { memperoleh informasi }\end{array}$ & 0 & 0 & 13 & 26 & 5 & 168 & 3,82 \\
\hline $\begin{array}{l}\text { Perbedaan divisitidakmenjadi } \\
\text { penghalang bagi karyawandalam } \\
\text { memperoleh informasi }\end{array}$ & 0 & 0 & 14 & 28 & 2 & 164 & 3,73 \\
\hline $\begin{array}{l}\text { karyawan dapat menerima informasi } \\
\text { dari berbagai sumber }\end{array}$ & 0 & 0 & 18 & 22 & 4 & 162 & 3,68 \\
\hline \multicolumn{1}{|c|}{ Rata-rata variabel } & & & & & & & 3,7 \\
\hline
\end{tabular}

Sumber: data diolah, 2019

Berdasarkan Tabel 12, terlihat bahw a rata-rata skor dari 9 pernyataan mengenai komunikasi yaitu sebesar 3,70 yang berada pada kisaran 3,41 - 4,20 yang berarti baik. Hal ini berarti responden dalam penelitian ini menilai komunikasi adalah baik. Hal ini ditunjang oleh persepsi responden tentng atasan mengkomunikasikan informasi mengenai tugas, kebijakan-kebijakan terkait organisasi sebanyk 21 orang yang setuju namun masih ada 19 responden yang kurang setuju. Pada indikator atasan mengkomunikasikan hasil kerja saya diketahui sebanyak 24 responden yang memberikan respon setuju, dan 18 responden yang memberikan respon kurang setuju. Pada indikator karyaw an dengan mudah dapat melakukan hubungan komunikasi dengan atasan terdapat 21 orang yang memberikan respon setuju, dan sebanyak 19 orang yang kurang setuju. Indikator setiap kendala pekerjaan yang terjadi di komunikasikan kepada atasan sebanyak 23 orang yang setuju dan 19 orang yang kurang setuju. Indikator karyaw an percaya terhadap rekan kerja di dalam melakukan pekerjaan sebanyak 25 orang yang setuju, 17 orang yang kurang setuju. Indikator perbedaan jabatan tidak menjadi penghalang bagi karyawan dalam memperoleh informasi sebanyak 26 orang yang setuju dan 13 orang yang kurang setuju. Pada indikator perbedaan divisi tidak menjadi penghalang bagi karyawan dalam memperoleh informasi sebanyak 28 orang yang setuju dan 14 orang yang kurang setuju. Indikator karyawan dapat menerima informasi dari berbagai sumber menyatakan sebanyak 22 orang yang setuju dan 18 orang yang kurang setuju.

3. Penilaian Res ponden Variabel Kepuas an kerja (Y)

Tabel 13. Distribusi Tangg apan Res ponden Pada Variabel Kepuasan Kerja

\begin{tabular}{|c|c|c|c|c|c|c|c|}
\hline \multirow[b]{2}{*}{ Indikator } & \multicolumn{5}{|c|}{ Jawaban } & \multirow[b]{2}{*}{ Total } & \multirow[b]{2}{*}{ Mean } \\
\hline & STS & $\mathrm{TS}$ & KS & $\mathrm{S}$ & SS & & \\
\hline $\begin{array}{l}\text { Karyawan dapat mengembangkan } \\
\text { potensi diridi perusahaan ini }\end{array}$ & 0 & 0 & 6 & 37 & 1 & 171 & 3,89 \\
\hline $\begin{array}{l}\text { Dengan bekerja pada perusahaan ini } \\
\text { karyawan memperoleh kesempatan } \\
\text { untuk sukses dalamberkarir }\end{array}$ & 0 & 0 & 8 & 33 & 3 & 171 & 3,89 \\
\hline $\begin{array}{l}\text { Gaji yang diberikan kepada karyawan } \\
\text { sesuai dengan kon tribusi yang karyawan } \\
\text { berikan kepada perusahaan }\end{array}$ & 0 & 0 & 15 & 25 & 4 & 165 & 3,75 \\
\hline $\begin{array}{l}\text { Pembayaran gaji yang diberikan kepada } \\
\text { karyawan sesuai dengan kesepakatan } \\
\text { yang telah ada }\end{array}$ & 0 & 0 & 15 & 25 & 4 & 165 & 3,75 \\
\hline $\begin{array}{l}\text { Kesempatan untuk mendapatkan } \\
\text { promosi di perus ahaan ini sangat banyak } \\
\text { dan karyawan bisa mendapatkan } \\
\text { kesempatan itu }\end{array}$ & 0 & 0 & 6 & 37 & 1 & 171 & 3,89 \\
\hline $\begin{array}{l}\text { Promosibis a karyawan peroleh karena } \\
\text { karyawan memiliki prestasi yang baik }\end{array}$ & 0 & 0 & 8 & 33 & 3 & 171 & 3,89 \\
\hline
\end{tabular}




\begin{tabular}{|l|c|c|c|c|c|c|c|}
$\begin{array}{l}\text { Pengawasan kerja membuat karyawan } \\
\text { tidaknyaman dalambekerja }\end{array}$ & 0 & 0 & 15 & 25 & 4 & 165 & 3,75 \\
\hline $\begin{array}{l}\text { Pengawasan yang dilakukan selama ini } \\
\text { membuat karyawan disiplin dan } \\
\text { bertanggung jawab }\end{array}$ & 0 & 0 & 15 & 25 & 4 & 165 & 3,75 \\
\hline $\begin{array}{l}\text { Jam kerja yang ditentukan diperusahaan } \\
\text { ini menurut karyawan sudah efektif }\end{array}$ & 0 & 0 & 6 & 37 & 1 & 171 & 3,89 \\
\hline $\begin{array}{l}\text { Lingkungan kerja diperusahaan ini } \\
\text { mendukung karyawan untuk bekerja }\end{array}$ & 0 & 0 & 8 & 33 & 3 & 171 & 3,89 \\
\hline Rata-rata variable & & & & & & & 3,83 \\
\hline
\end{tabular}

Sumber: data diolah, 2019

Berdasarkan Tabel 13, terlihat bahwa rata-rata skor dari 10 pernyataan mengenai kepuasan kerja yaitu sebesar 3,83 yang berada pada kisaran 3,41 - 4,20 yang berarti baik. Hal ini berarti responden dalam penelitian ini menilai kepuasan kerja adalah baik. Hal ini didukung oleh respon responden terhadap indikator karyaw an dapat mengembangkan potensi diri di perusahaan ini yang menyatakan setuju sebanyak 35 orang. pada indikator dengan bekerja pada perusahaan ini karyawan memperoleh kesempatan untuk sukses dalam berkarir sebanyak 33 orang yang merespon setuju, pada indikator gaji yang diberikan kepada karyawan sesuai dengan kontribusi yang karyawan berikan kepada perusahaan sebanyak 25 orang yang merespon setuju. indikator pembayaran gaji yang diberikan kepada karyawan sesuai dengan kesepakatan yang telah ada sebanyak 25 orang yang setuju. Indikator mendapatkan promosi di perusahaan ini sangat banyak dan karyawan bisa mendapatkan kesempatan disetujui oleh 37 orang. pada indikator promosi bisa karyawan peroleh karena karyaw an memiliki prestasi yang baik sebanyak 33 orang yang setuju. Indikaktor pengawasan kerja membuat karyaw an tidak nyaman dalam bekerja sebanyak 25 orang yang menyatakan setuju. Pengawasan yang dilakukan selama ini membuat karyaw an disiplin dan bertanggung jaw ab dijaw ab setuju oleh 25 orang. indikator jam kerja yang ditentukan di perusahaan ini menurut karyaw an sudah efektif dijaw ab setuju oleh 37 orang, dan Lingkungan kerja diperusahaan ini mendukung karyaw an untuk bekerja dijaw ab setuju oleh 33 orang.

Uji validitas digunakan untuk mengukur sah atau valid tidaknya suatu kuesioner. Suatu kuesioner dikatakan valid jika pertanyaan pada kuesioner mampu untuk mengungkapkan sesuatu yang akan diukur oleh kuesioner tersebut. Uji validitas pada penelitian ini dilakukan hanya terhadap variabel kepemimpinan yang dibentuk oleh 3 indikator. Hasil uji disajikan pada Tabel 14.

Tabel 14. Hasil Uji Validitas Variabel Kepemimpinan

\begin{tabular}{|c|c|c|c|}
\hline No & Item & Koefisien korelasi & Keterangan \\
\hline 1 & $\mathrm{X} 1.1$ & 0,988 & Valid \\
\hline 2 & $\mathrm{X} 1.2$ & 0,988 & Valid \\
\hline 3 & $\mathrm{X} 1.3$ & 0,974 & Valid \\
\hline 4 & $\mathrm{X} 1.4$ & 0,966 & Valid \\
\hline 5 & $\mathrm{X} 1.5$ & 0,953 & Valid \\
\hline 6 & $\mathrm{X} 1.6$ & 0,824 & Valid \\
\hline 7 & $\mathrm{X} 1.7$ & 0,988 & Valid \\
\hline
\end{tabular}

Sumber: Lampiran 2.

Berdasarkan Tabel 14, diketahui bahwa seluruh indikator dalam variabel kepemimpinan memiliki koefisien korelasi yang lebih besar dari 0,3. Jadi dapat disimpulkan bahw a seluruh indikator telah memenuhi syarat validitas data.

Tabel 15. Hasil Uji Validitas Variabel Komunikasi $\left(\mathrm{X}_{2}\right)$

\begin{tabular}{|c|c|c|c|}
\hline No & Item Pernyataan & Koefisien korelasi & Keterangan \\
\hline 1 & X2.1 & 0,971 & Valid \\
\hline 2 & X2.2 & 0,964 & Valid \\
\hline 3 & X2.3 & 0,965 & Valid \\
\hline 4 & X2.4 & 0,947 & Valid \\
\hline 5 & X2.5 & 0,931 & Valid \\
\hline
\end{tabular}




\begin{tabular}{|l|l|l|l|}
6 & $\mathrm{X} 2.6$ & 0,833 & Valid \\
\hline 7 & $\mathrm{X} 2.7$ & 0,808 & Valid \\
\hline 8 & $\mathrm{X} 2.8$ & 0,862 & Valid \\
\hline 9 & $\mathrm{X} 2.9$ & 0,936 & Valid \\
\hline
\end{tabular}

Sumber: Lampiran 2.

Berdasarkan Tabel 15, diketahui bahwa seluruh indikator dalam variabel komunikasi memiliki koefisien korelasi yang lebih besar dari 0,3. Jadi dapat disimpulkan bahwa seluruh indikator telah memenuhi syarat validitas data.

Tabel 16. Hasil Uji Validitas Variabel Kepuasan Kerja (Y)

\begin{tabular}{|c|c|c|c|}
\hline No & Item pernyataan & Koefisien korelasi & Keterangan \\
\hline 1 & Y1 & 0,557 & Valid \\
\hline 2 & Y2 & 0,810 & Valid \\
\hline 3 & Y3 & 0,900 & Valid \\
\hline 4 & Y4 & 0,900 & Valid \\
\hline 5 & Y5 & 0,557 & Valid \\
\hline 6 & Y6 & 0,810 & Valid \\
\hline 7 & Y7 & 0,900 & Valid \\
\hline 8 & Y8 & 0,900 & Valid \\
\hline 9 & Y9 & 0,557 & Valid \\
\hline 10 & Y10 & 0,810 & Valid \\
\hline
\end{tabular}

Sumber: Lampiran 2

Berdasarkan Tabel 16, diketahui bahwa seluruh indikator dalam variabel kepuasan kerja memiliki koefisien korelasi yang lebih besar dari 0,3. Jadi dapat disimpulkan bahwa seluruh indikator telah memenuhi syarat validitas data.

Uji Reliabilitas adalah alat untuk mengukur suatu kuesioner yang merupakan indikator dari variabel atau konstruk. Suatu kuesioner dikatakan reliabel atau handal jika jawaban seseorang terhadap pernyataan adalah konsisten atau stabil dari waktu ke waktu. Untuk mengukur reliabilitas dengan uji statistik cronbach alpha lebih besar dari 0,60. Hasil uji menunjukkan nilai cronbach alpha untuk variabel ditunjukkan pada tabe 17 berikut.

Tabel 17. Uji Reliabilitas

\begin{tabular}{|l|c|c|}
\hline \multicolumn{1}{|c|}{ Variabel } & Alpha Cronbach & Keterangan \\
\hline Kepemimpinan & 0,984 & Reliabel \\
\hline Komunikasi & 0,975 & Reliabel \\
\hline Kepuasan kerja & 0,930 & Reliabel \\
\hline
\end{tabular}

Berdasarkan tabel diatas kepemimpinan sebesar 0,984, variabel komunikasi sebesar 0,975, dan variabel kepuasan kerja sebesar 0,930. Sehingga dapat disimpulkan bahwa semua variabel telah memenuhi syarat reliabilitas data.

Hasil Pengujian Asumsi Klasik merupakan model regresi yang baik adalah model regresi yang di dalamnya tidak terdapat masalah data yang distribusinya tidak normal, masalah multikolineritas, dan masalah heteroskedastisitas. Untuk itu maka dilakukan uji model regresi harus dilakukan dengan pengujian asumsi klasik terhadap model regresi yang akan digunakan. Apabila model regresi tidak lolos dalam pengujian ini maka model regresi tidak dapat digunakan. Berikut ini disajikan hasil pengujian asumsi klasik yang meliputi uji normalitas data, uji multikolinieritas dan uji heteroskedastisitas. 


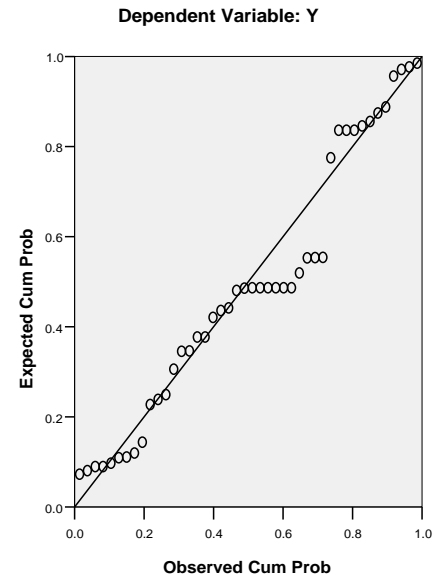

Gambar 1. Uji Normalitas Sebaran

Berdasarkan Gambar 1, terlihat bahwa titik-titik menyebar di sekitar garis diagonal. Oleh karena berdasarkan uji normalitas, analisis regresi layak digunakan.

Tabel 18. Tabel Hasil Uji Multikolinieritas

\begin{tabular}{|c|c|c|c|}
\hline \multicolumn{4}{|c|}{ Coefficients $^{a}$} \\
\hline \multirow{2}{*}{\multicolumn{2}{|c|}{ Model }} & \multicolumn{2}{|c|}{ Collinearity Statistics } \\
\hline & & Tolerance & VIF \\
\hline \multirow[t]{2}{*}{1} & $\overline{X 1}$ & ,931 & 1,074 \\
\hline & $\mathrm{X} 2$ & ,931 & 1,074 \\
\hline
\end{tabular}

a. Dependent Variable: $Y$

Sumber:Lampiran 2.

Pada Tabel 18, terlihat bahwa hasil perhitungan nilai tolerance menunjukkan tidak ada variabel bebas yang memiliki nilai tolerance kurang dari $10 \%(0,100)$. Demikian juga dengan nilai VIF yang semuanya di bawah 10 . Hal ini berarti dalam model regresi tidak terjadi multikolinieritas.

Uji heteroskedastisitas dapat dilihat dengan mendeteksi apakah ada tidaknya pola tertentu pada grafik (scater plot) yang dihasilkan, dimana sumbu $\mathrm{x}$ dan y yang telah diprediksi dan sumbu $\mathrm{y}$ adalah residual (y prediksi - y sesungguhnya) yang telah di studentized. dari grafik yang dihasilkan pada lampiran 8, terlihat titik titik menyebar secara acak, tidak membentuk sebuah pola tertentu yang jelas, serta tersebar baik diatas maupun dibawah angka 0 pada sumbu Y. hal ini berarti tidak terjadi heteroskedasitas pada model regresi .

Gambar 2. Uij Heteroskedasitas

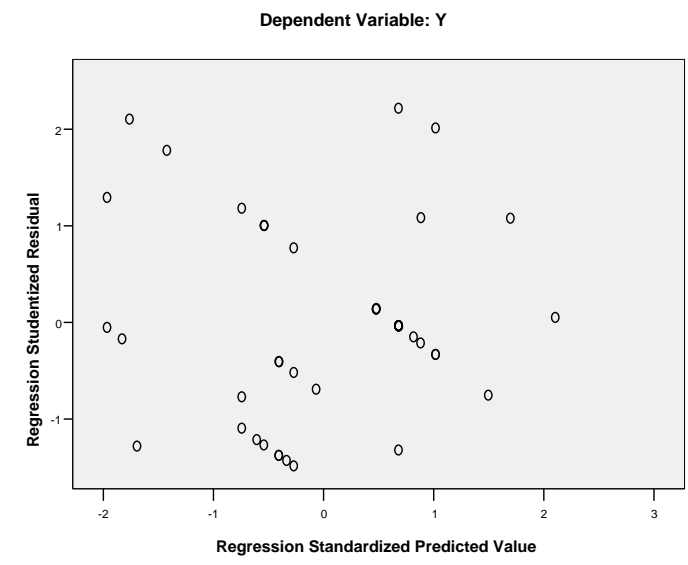


Model yang digunakan dalam menganalisa pengaruh kepemimpinan, komunikasi, terhadap kepuasan kerja adalah model regresi linier berganda dengan bantuan SPSS versi 22.0 serta diuji dengan tingkat signifikansi 5\%. Dalam model regresi linier berganda ini, kepemimpinan (X1), komunikasi (X2), digunakan sebagai variabel bebas, sedangkan kepuasan kerja (Y) sebagai variabel terikat.

Pada Tabel 19 berikut dapat dilihat hasil analisis pengaruh kepemimpinan, komunikasi terhadap kepuasan kerja.

Tabel 19. Hasil Analisis Regresi Linier Berganda

\begin{tabular}{|c|c|c|c|c|c|c|}
\hline \multirow{2}{*}{\multicolumn{2}{|c|}{ Model }} & \multicolumn{2}{|c|}{$\begin{array}{c}\text { Unstandardized } \\
\text { Coefficients }\end{array}$} & \multirow{2}{*}{$\begin{array}{c}\begin{array}{c}\text { Standardized } \\
\text { Coefficients }\end{array} \\
\text { Beta }\end{array}$} & \multirow[b]{2}{*}{$\mathrm{t}$} & \multirow{2}{*}{ Sig. } \\
\hline & & B & Std. Error & & & \\
\hline \multirow[t]{7}{*}{1.} & Kepemimpinan & & & & & \\
\hline & & 0,534 & 0,109 & 0,606 & 4,915 & 0,000 \\
\hline & Komunikasi & 0,357 & 0,101 & 0,438 & 3,548 & 0,001 \\
\hline & Konstanta = & & & 12,294 & & \\
\hline & R Square & & & 0,419 & & \\
\hline & $F_{\text {hitung }}$ & & & 14,810 & & \\
\hline & Sig. F Fitung & & & 0,000 & & \\
\hline
\end{tabular}

Sumber: Lampiran

Koefisien Determinasi (R2) bertujuan untuk mengetahui seberapa besar variabel independen mampu menjelaskan dan mempengaruhi variabel dependen. Nilai koefisien determinasi adalah antara nol dan satu. Nilai R2 yang kecil berarti kemampuan variabel-variabel independen dalam menjelaskan variasi dependen terbatas. Nilai yang mendekati satu berarti variabel-variabel indepenen memberikan hampir semua informasi yang dibutuhkan untuk memprediksi variasi variabel dependen (Ghozali : 2009)

Persamaan yang di gunakan adalah sebagai berikut :

$\mathrm{D}=\mathrm{R}^{2} \mathrm{X} 100 \%$ atau $\mathrm{D}=$ Adjs $\mathrm{R}^{2} \mathrm{X} 100 \%$

Tabel 20. Hasil Uji Koefisien Determinasi

Model Summary

\begin{tabular}{|l|r|r|r|r|}
\hline Model & $R$ & $R$ Square & Adjusted $R$ Square & $\begin{array}{c}\text { Std. Error of the } \\
\text { Estimate }\end{array}$ \\
\hline 1 &, $644^{\mathrm{a}}$ &, 415 &, 403 & 4,27225 \\
\hline
\end{tabular}

a. Predictors: $($ Constant $), \operatorname{Komunikasi}\left(\mathrm{X}_{2}\right)$, Kepemimpinan $\left(\mathrm{X}_{1}\right)$

b. Dependent Variable: Kepuasan kerja (Y)

Sumber: Hasil Penelitian, 2018.

Berdasarkan Tabel 20, Analisis regresi yang digunakan adalah analisis regresi berganda sehingga koefisien determinasi yang digunakan adalah $R$ square (koefisien determinasi terkoreksi). Nilai koefisien yang diperoleh adalah sebesar 0.415 . Nilai determinasinya menjadi $0.415 \times 100 \%=$ $41.5 \%$. Hal ini mengindikasikan bahwa semangat kerja dijelaskan $41.5 \%$ oleh variabel 
kepemimpinan dan motivasi kerja sedangkan sisanya sebesar $58.5 \%$ dipengaruhi oleh variabel lain yang tidak termasuk dalam penelitian ini.

\section{KESIMPULAN}

Simpulan yang dapat ditarik bahwa hasil analisis dan pembahasan mengenai pengaruh kepemimpinan, komunikasi, terhadap kepuasan kerja karyaw an di Kuta Paradiso Hotel maka dapat ditarik kesimpulan sebagai berikut: hasil analisis variabel pengaruh kepemimpinan dan komunikasi memiliki pengaruh fositif dan signifikan terhadap kepuasan kerja karyawan dengan nilai t hitung 4,915 dengan t tabel sebesar 1,6 ini berarti semakin baik kepemimpinan maka semakin tinggi kepuasan kerja karyawan di Kuta Paradiso Hotel. Hasil analisis variabel kepemimpinan dan komunikasi yang mana lebih berpengaruh terhadap kepuasan kerja karyawan yaitu Komunikasi berpengaruh positif dan signifikan terhadap kepuas an kerja dengan nilai $t$ hitung sebesar 3,548 dengan t tabel sebesar 1,6 ini berarti semakin baik komunikasi maka semakin tinggi kepuasan kerja karyaw an di Kuta Paradiso Hotel.

\section{Ucapan terima kasih}

Penulis menyadari sepenuhnya penyelesaian laporan ini tidak terlepas dari masukan dan arahan dari berbagai belah pihak. Oleh sebab itu penulis tidak lupa mengucapkan terima kasih kepada:Bapak Dr. Drs. I Nyoman Sunarta, M.Si. selaku Dekan Fakultas Pariwisata; Ibu Dra. Anak Agung Putri Sri, M.Si. selaku Koordinator Program Studi Diploma IV Pariwisata Fakultas Pariwisata Universitas Udayana; Ibu Putu Ratih Pertiwi, SST.Par.,M.Par.,M.Rech., pembimbing akademik sekaligus selaku penguji yang telah mengarahkan dan memberikan banyak masukan serta saran dalam penyusunan laporan akhir ini; Bapak Drs. Ida Bagus Ketut Astina, M.Si., selaku pembimbing I yang telah memberikan petunjuk, bimbingan, dan saran dalam penyusunan laporan akhir ini; Ibu Fanny Maharani Suarka, SST.Par., M.Par., selaku pembimbing II yang telah memberikan banyak petunjuk, bimbingan, dan saran dalam penyusunan laporan akhir ini; Bapak Drs. I Nyoman Jamin Ariana, M,Par selaku penguji yang telah memberikan saran dalam menyusun laporan akhir ini; Ibu Luh Gede Leli Kusuma Dewi, S.Psi.,M.Par. selaku penguji yang telah memberikan saran dalam menyusun laporan akhir ini; Seluruh Dosen Fakultas Pariwisata Universitas Udayana yang tidak dapat penulis sebutkan satu per satu, yang telah mendidik dan memberikan ilmunya kepada penulis.; Seluruh Staff di lingkungan Fakultas Pariwisata Universitas Udayana; Seluruh Staff dan Manajemen Kuta Paradiso Hotel Bali yang telah membantu dan memberikan informasi selama melakukan penelitian; Kedua Orang Tua Bapak I Ketut Gelgel dan Ibu Ni Wayan Sariati yang telah membiayai seluruh semasa perkuliahan, dan memberi dukungan serta semangat untuk menyelesaikan laporan akhir ini. serta saudara saya yang sangat membantu dan memotivasi dalam penyelesaian laporan akhir ini; Saudara dan Keluarga saya yang senantiasa membantu dan memberikan motivasi dalam penyelesaian laporan akhir ini; Seluruh teman-teman seperjuangan Diploma IV Pariwisata angkatan 2014 yang sama-sama berjuang dan senantiasa membantu memberikan masukan, dukungan dan informasi selama masa perkuliahan hingga terselesaikan laporan akhir ini.

\section{DAFTAR PUSTAKA}

Anoraga. 2004. Kepemimpinan Dalam Manajemen. Jakarta : PT Raja Grafindo Persada Bramantyo, Andre, 2010. Pengaruh Kepemimpinan dan Komunikasi Terhadap Kinerja Karyawan PT. Inti Sukses Garmindo Bawen.Skripsi. Semarang. Jurusan Manajemen Fakultas Ekonomi Universitas Negeri Semarang.

Darmajati, 2001. Pengantar Akomodasi Dan Restoran. PT Wijaya. Jogja

Effendy, Omong Uchjana. 2005. Kepemimpinan Dan Komunikasi. Bandung : Alumni.

Febriyandi, Rensius, 2016. Pengaruh Kepemimpinan dan Komunikasi Terhadap Kinerja Karyawan

PT. Kereta Api Indonesia Sub.Divisi Regional III.2 Tanjung Karang Bandar Lampung.Skripsi. Lampung. Jurusan Manajemen Fakultas Ekonomi dan Bisnis Universitas Lampung.

Gorda, I Gusti Ngurah. 2004. Manajemen Sumber Daya Manusia. Denpasar : Widya Kirya. 
Handoko, T. Hani. 2004 Manajemen Organisasi. Yogyakarta : BPFE.

Hasan. 2002. Metode Penelitian. Jakarta. Bina Aksara

Hasibuan S.P. 2007. Manajemen Sumber Daya Manusia, cetakan kesembilan PT Bumi Aksara. Manulang. Jakarta.

Kountur, Ronny, 2004. Metode penelitian untuk penulisan skripsi dan tesis. PPM. Jakarta.

Martoyo. 2009. Pengantar Manajemen. Jakarta, PT. Bumi Aksara

Mathis Dan Jakson 2000. Perilaku Keorganisasian. Graha Ilmu. Yogyakarta

Robbins, Stphen P. 2004. Perilaku Organisasi. Jakarta : PT. Prenhllindo.

Ronny Kountur. 2003. Metode Penelitian Untuk Penulisan Skripsi Dan Tesis. Seri Umum no. 5. Penerbit PPM

Rumekso.2004. House Keeping Hotel. Edisi Ketiga. Yogyakarta : Penerbit Andi

Sambodo dan Bagyono. 2006. Dasar-dasar Kantor Depan Hotel. Yogyakarta : penerbit Andi.

Siagian, Sondang P. 2004. Manajemen Sumber Daya Menusia. Jakarta : Bumi Aksara

Sinaga, Nita Anggreni, 2017. Pengaruh Kepemimpinan dan Komunikasi Terhadap Kinerja Karyawan PT. Galva Technologies Kantor Perwakilan Medan. Skripsi. Medan. Jurusan Manajemen Fakultas Ekonomi Universitas Sumatera Utara.

Sri Sulastinigrum, BA. 2000. Pengantar Akomodasi Dan Restoran

Sugiyono, 2001. Metode Penelitian, Alfabeta Bandung.

Sugiyono, 2008. Metode Penelitian Kuantitatif Kualitatif dan R\&D. Bandung: Alfabeta.

Suharsimi, 2006. Prosedur Penelitian Suatu Pendekatan Praktik. Jakarta: Rineka Cipta.

Sulastiyono Agus. 2001. Housekeeping, Perhotelan. Andi Yogya, Grasindo. Jakarta

Sunyoto, Danang, 2012, Teori, Kuisioner, Dan Analisis Data Sumber Daya Manusia (Praktik Penelitian), CAPS (Center For Academic Publishing Service), Yogyakarta.

Sutrisno, Edy. 2009. Manajemen Sumber Daya Manusia. Edisi Pertama. Cetakan Ke-4. Jakarta:Fajar Interpratama Offset

Utama, Rai, \& mahadewi, 2012, Metodelogi Peneitian Pariwisata Dan Perhotelan, CV. AndiOffset, Yogyakarta.

Widjaja, 1993. Pengertian komunikasi. Yogya, Grasindo. Jakarta. 